\title{
回転立体連続脳動脈撮影について
}

\author{
柴田 孝行・伊藤 明雄・宮地茂・梶田 泰一・森美雅
}

\section{Rotational Stereoscopic Cerebral Angiography}

\author{
Takayuki Shibata, Akio Ito, Shigeru MiYaji, Yasukazu KajITA \\ and Yoshimasa MORI
}

Department of Neurosurgery, Nagoya Ekisaikai Hospital, Nagoya

\begin{abstract}
Cerebral angiography is the most important diagnostic procedure for aneurysms. However, it is often necessary to obtain several oblique views in order to confirm the location, shape, and origin of an aneurysm. Recently, the development of a rotational stereoscopic cerebral angiography (RSCAG) system, consisting of a Diagnost $\mathrm{N}$ unit, an image intensifier, and a camera, was reported. Subsequently a similar unit was devised, in which the image intensifier was replaced by a film changer CXC-U1. The X-ray tube and film changer are rotated around the head, which is positioned at the isocentrum of the tube/film changer unit. During the rotation procedure, sequential 3-persecond $\mathrm{X}$-ray exposures at angles differing by about $5^{\circ}$ yield stereoscopic images. The total exposure is $60^{\circ}$.

Six patients with aneurysms underwent both conventional angiography and RS-CAG. Another 20 patients were studied by RS-CAG alone. RS-CAG more clearly depicted the location, size, and shape of aneurysms. Overlapping arteries and arterial loops were also better visualized with RS$\mathrm{CAG}$, and the time required for examination was shorter than that of conventional angiography. In most cases, one RS-CAG examination was sufficient for evaluation of unilateral lesions within the territory of the internal cerebral artery.
\end{abstract}

Key words: aneurysm, stereoscopic cerebral angiography

\section{I はじめに}

脳動脈瘤の検索に脳動脈撮影は不可欠な検査法である。 通常, 前後像および側面像だけでは動脈瘤の形態や周囲の 動脈との位置関倸を確認できず，適当な角度の斜位撮影が 必要となることが多い，時には二度，三度と角度を变えた 斜位撮影が必要となることもある。患者への侵襲をできる ボけ少なくして脳動脈瘤と近接動脈との詳しい位置関倸を 知ることが重要である，我々は，正面上り検側に向かって 約 5 度の間隔で連続的に脳動脈撮影を行い，連続的に立体 的血管像を得る装置を考案し，臨床的に利用しているので
報告する。同様の目的で image intensifier (I.I.) とカイラ またはシネを使用した間接撮影法による回転立体連続撮影 法1)が報告されているが，我々の方法は通常のつィルムを 使用した直接撮影法で，桩大撮影す同一方法で可能であ る.

\section{II 方法}

Diagnost Nの管球打よび I.I. を支えるマームの回転を 利用してI.I.の代りに CXC-U1 film changerを取り付け, 管球および film changer 頭部を中心に同心円状に回転さ せながら，約 5 度ごとに連続脳動脈撮影を行った(Fig.

名古屋掖済会病院腷神経外科

Address reprint requests to: T. Shibata, M.D., Department of Neurosurgery, Nagoya Ekisaikai Hospital, 4-66 Shonen-cho, Nakagawa-ku, Nagoya 454.

受稿 1987 年 5 月 11 日 受理 1988 年 2 月 19 日 


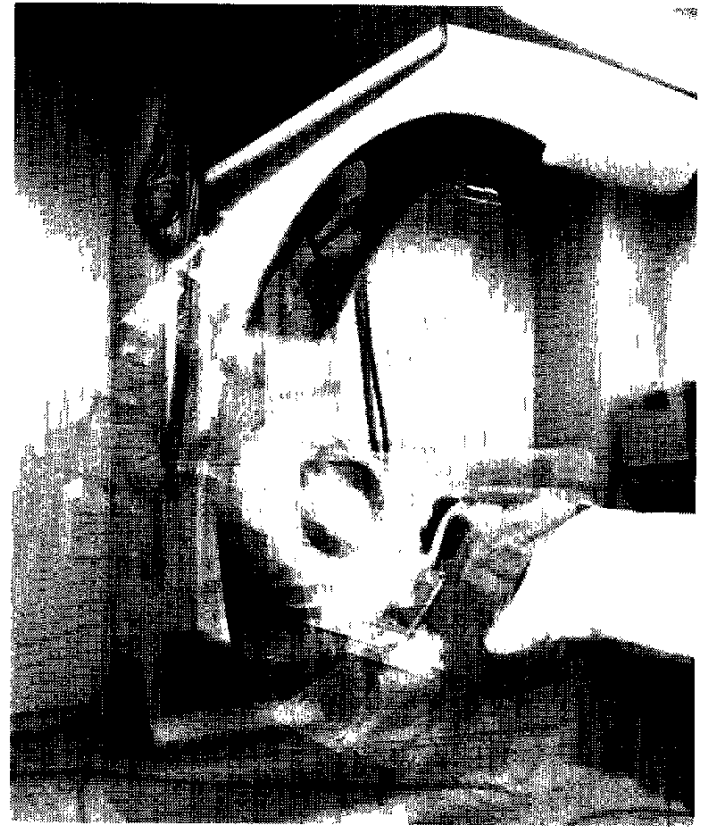

Fig. 1 Rotating Diagnost $\mathrm{N}$ with film changer CXC-U1.

1)。造影剤は60\%アンギオグラフィンをたは $300 \mathrm{mgI}$ 人ト りザマイドを用い，毎秒 $9 \mathrm{~m} l$, 総量 $25 \mathrm{~m} l$ を総頸動脈より 注入した。フィルムは大角の普通フィルムを使用した。

撮影は，正中上り険側沉60度の範囲内て回転連続撮影を 行った。症例によっては対側の総頸動脈を王迫して撮影を 行い, 両側の内頸動脈造影が1回の回転連続撮影で終了し た淀例もあった。回忶連秸撮影で隣合った 2 枚のフィルム を並べて置くと立体視が可能で，角度の变った連続的立体 斜位像が得られた。

\section{III 臨 床 結 果}

1984年11月以来1987年 2 月までに，回転立体連続脳動脈 撮影は49例66回行加九た。この5ち，外側型脳队出血で脳 動脈瘤破裂の可能性が疑われたりのやクモ膜下出血で脳動 脈瘤の見出せなかったもの14例23回，クモ膜下出血で脳動 脈溜が見付かったもの26例32回，脳動脈瘤の術後険査とし て行ったもの9例11回であった，脳動脈瘤の部位恃，26例 中内頸動脈 9 個, 前大脳動脈12個, 中大脳動脈13個, 計34 個であった。

術前㭘查として回転立体連続脳動脈撮影の汪かに一側の 頸動脈撮影を追加したもの3 例, 両側の頸動脈撮影を追加 したもの2 例，頭蓋底撮影を追加したもの1例で，他の20 例は回転立体連続脳動脈撮影のみで頸部クリッピングが行 われた。

症例：51才，男性。1986年3月23日，激しい頭痛で発症
し，CT 娭查でクモ膜下出血の所見が認められ，5月16日， 名古屋掖済会病院に転医してきた，神経学的には特記すべ き所見は認められなかった。 5 月19日，アンギオグラフィ ン毎秒 $9 \mathrm{ml}$, 総量 $25 \mathrm{ml}$ を使用して左回転立体連秸脳動脈 撮影を施行したところ，左中大脳動脈分伎部に漂篂状の動 脈瘤を認め，親動脈々動脈瘤頸部の位置関係を知る上で有 益であった(Fig. 2)，引き続き右沉脳動脈撮影を行った が，異常は認められなかった。 5 月21日，開頭術を行い， $\mathrm{M}_{2}$ 起始部に広い, 頸を持った脳動脈瘤を認め, 杉田タリッ プNo.18で頸部処理を行った。術後クリッピングの結果 を確認し，6月 5 日，なんら脱落症状を認めず，全治退院 した.

\section{$N$ 考察}

脳血管撮影で正面，側面の二方向撮影だけでは脳動脈瘤 の形態や近接した動脈との位置関係を十分理解できないこ とが多い，そこで，斜位撮影，頭蓋底撮影，angiotomography $^{2)}$ やstereoscopic angiography が必要上なってくる. 斜位撮影も1回の撮影だけで的確な情報が得られるとは限 らず，何回妇角度を变克て撮影しなければならないことが あり，その場合，それだけ患者に与える侵襲も大きくな る。

Cornelis $5^{1)}$ は Diagnost NKI.I. $70 \mathrm{~mm}$ camera t使用 して，毎秒 4 枚，5度ごとに管球を回転しながら $90 \sim 180$ 度の連続撮影を行い，脳動脈瘤の検索に有益であったと報 告している.Voigt ら4,5! も同様の報告を行い，撮影時の照 射時間が20 40 msecであればフィルム上の振れは感じら れないとし，本た隣合せた2枚のフィルムから立体視が可 能で，っとも立体視に適した角度は 5 度であると言って いる，一方，乙供3 は独自の回転装置と $35 \mathrm{~mm}$ シネを用い て180度の回転連秸撮影を行っている。しかし，フィルム の現像に時間のかかること，特殊な読影装置を必要々する こと，I.I. 在使用した間接撮影であるために解像力に限界 があることなどの欠点がある。我々はこれらの点を改善す るために通常のフィルムによる直接撮影を試みた。すなわ ち，Diagnost $\mathrm{N}$ の透視用ブラウン管を取り外し，同部に CXC-U1 film changer 取り付け，頭部を中心に管球和 よび film changerを同心円状江回転させながら毎秒 3 枚, 約 5 度ごとの連続撮影を行った。

当初は脳動脈瘤の検索江正面, 側面の二方向撮影を行 い，斜位撮影を必要としたときに通常の脳動脈撮影の一環 として斜位撮影の代りに回転立体連続撮影を行った。 その 後, 側面撮影は中大脳動脈之前大脳動脈の重なりが多く, 診断的価值が低く，正中から60度までの回転連続撮影で十 分であることが判ったので，最近では正中位から検側に60 


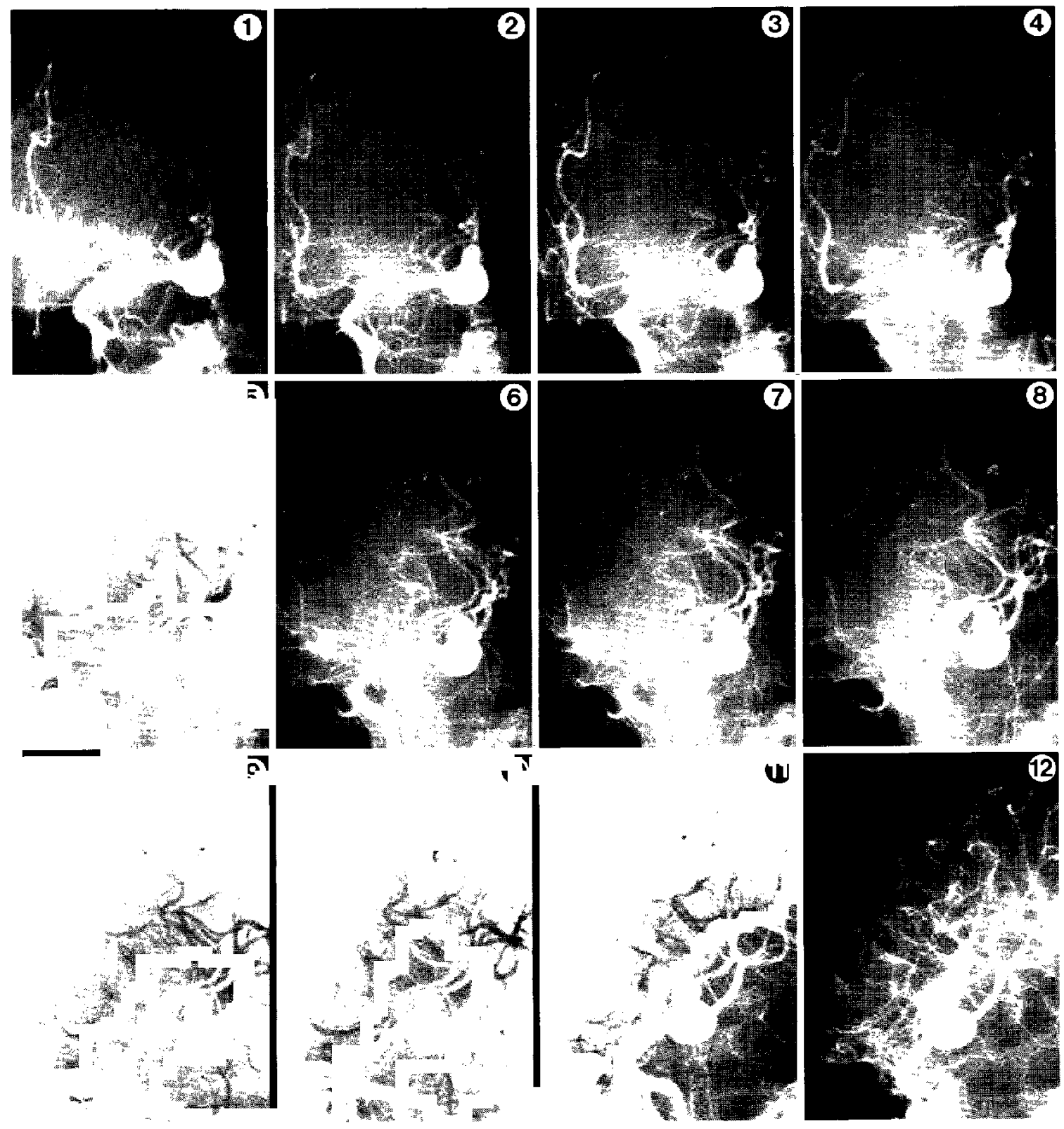

Fig. 2 Images obtained sequentially at $5^{\circ}$ intervals yield stereoscopic views. The location and shape of the aneurysm are clearly demonstrated.

度前後の回転立体連続撮影を単独に行っている，連続的に 角度が变ることに上り，動脈瘤と近接動脈の重なりが解け て頑部および動脈瘤の形態がはっきりしてくるもの，動脈 瘤を疑わ机た血管が徐々にloop となってゆくものなど， 一定の方向かららの撮影では得られない多くの情報が得られ る. 一側の内頸動脈領域の検索には 1 回の回転立体連続撮

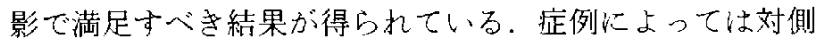
の総頸動脈を王迫して行った 1 回の回転立体連続撮影で両
側の内頸動脈領域が十分検索できたものも京り，検查時間 が大幅に短縮された。ささらに，隣合せた 2 枚のフィルムか ら立体視が可能で， 5 度ごとの立体連続斜位像が得られ た。なお，抎大撮影も可能で，桩大された立体連続斜位像 が得られ心，照射時間を25 msecで行っているが，従来の 連続撮影像との間に肉眼的な振れは感じられなかった。造 影剂は毎秒 $9 \mathrm{~m} l$, 総量 $25 \mathrm{~m} l$ 光総頸動脈か心注入寸ると, 少なくとも 4 秒間，问転角度にして約60度の間は動脈相の 
造影が可能であった。臨床的には回転角度は60度あれば十 分であり，90度以上の回転は必要でない，造影剤を棇量 $25 \mathrm{~m} l$ 注入することによる副作用は $10 \mathrm{ml}$ 注入時に比べ多 少熱感が強い程度で，非イオン性造影郕を使用すればまっ たく問題はなかった。

従来の I.I. を使った間接的な回転連続撮影に比べ，本検 查法は解像力が優九ていること, 現像時間が短く, 検查時 間が短縮できること，読影に特殊な装置を必要としないこ となどが優れている，また，通常の脳血管撮影に比べても 多くの場合，一側の内頸動脈領域の検査か 1 回の回転立体 連続脳動脈撮影で済も大めに患者への侵襲も少なく，検查 時間も大幅に短縮できた。脳動脈瘤の泳かに脳動静脈奇形 や血管に富えだ脳腫瘍などにも適応がある。一方，本検査 法の欠点は，同一条件で単純撮影の回転連続撮影を追加し なければ subtructionができないことである。最近の I.I と film changerの切り換えが簡単にできる血管撮影装置 で，管球と film changer を支点るアームを毎秒15度の回転 速度に改造できれば，本検查法は一般病院で施行可能であ る。

\section{V 結 語}

1. Diagnost NのI.I.に代りCXC-U1 film changer
取り付けた回転立体連続脳動脈撮影装置を考案し，脳動脈 撮影で正中より60度むでの連続的立体斜位造影が得られ た。

2. 26例32回，脳動脈瘤の術前検査として使用し，脳動 脈瘤の検索に有益であった。

\section{文献}

1) Cornelis G, Bellet A, Van Eygen B, Roisin PH, Libon E Rotational multiple sequence roentgenography of intracranial aneurysm. Acto Radiol [Diagn] (Stockholm) 13: 74-76, 1972

2) Du Boulay GH, Jackson DC: Cranial angiotomography. Clin Radiol 16: 148-153, 1965

3）乙供通則：連続回転立体撮影法一新放射楾猃断法(第 3 報) 一連続回転立体撮影装直(ST Type I)ならびにシネフィルム立 体投影機の試作一。 Neurol Med Chir (Tokyo) 24: 840-847, 1984

4) Thron A, Voigt K: Rotational cerebral angiography: Procedure and value. AJNR 4: 289-291, 1983

5) Voigt K, Stoeter P, Peterson D: Rotational cerebral roentgenography. 1. Evaluation of the technical procedure and diagnostic application with model studies. Neuroradiology 10: 95-100, 1975

〔別刷請求先：=454 名古屋市中川区松年町4-66，名古屋掖济会 病院脳神程外科，柴田孝行] 